\title{
Mobile Phone Surveys for Collecting Population-Level Estimates in Low- and Middle-Income Countries: A Literature Review
}

Dustin G Gibson ${ }^{1}$, MS, PhD; Amanda Pereira ${ }^{1}$, MSPH; Brooke A Farrenkopf ${ }^{1}$, MSPH; Alain B Labrique ${ }^{1}$, MHS, MS, PhD; George W Pariyo ${ }^{1}$, MBChB, PhD; Adnan A Hyder ${ }^{1,2}$, MPH, MD, PhD

${ }^{1}$ Department of International Health, Johns Hopkins Bloomberg School of Public Health, Baltimore, MD, United States

${ }^{2}$ Berman Institute of Bioethics, Johns Hopkins University, Baltimore, MD, United States

Corresponding Author:

Dustin G Gibson, MS, PhD

Department of International Health

Johns Hopkins Bloomberg School of Public Health

$615 \mathrm{~N}$ Wolfe St

Baltimore, MD, 21205

United States

Phone: 14432878763

Fax: 14106141419

Email: dgibso28@jhu.edu

\section{Abstract}

Background: National and subnational level surveys are important for monitoring disease burden, prioritizing resource allocation, and evaluating public health policies. As mobile phone access and ownership become more common globally, mobile phone surveys (MPSs) offer an opportunity to supplement traditional public health household surveys.

Objective: The objective of this study was to systematically review the current landscape of MPSs to collect population-level estimates in low- and middle-income countries (LMICs).

Methods: Primary and gray literature from 7 online databases were systematically searched for studies that deployed MPSs to collect population-level estimates. Titles and abstracts were screened on primary inclusion and exclusion criteria by two research assistants. Articles that met primary screening requirements were read in full and screened for secondary eligibility criteria. Articles included in review were grouped into the following three categories by their survey modality: (1) interactive voice response (IVR), (2) short message service (SMS), and (3) human operator or computer-assisted telephone interviews (CATI). Data were abstracted by two research assistants. The conduct and reporting of the review conformed to the Preferred Reporting Items for Systematic Reviews and Meta-Analyses (PRISMA) statement.

Results: A total of 6625 articles were identified through the literature review. Overall, 11 articles were identified that contained 19 MPS (CATI, IVR, or SMS) surveys to collect population-level estimates across a range of topics. MPSs were used in Latin America $(n=8)$, the Middle East $(n=1)$, South Asia $(n=2)$, and sub-Saharan Africa $(n=8)$. Nine articles presented results for 10 CATI surveys $(10 / 19,53 \%)$. Two articles discussed the findings of 6 IVR surveys $(6 / 19,32 \%)$. Three SMS surveys were identified from 2 articles $(3 / 19,16 \%)$. Approximately 63\% (12/19) of MPS were delivered to mobile phone numbers collected from previously administered household surveys. The majority of MPS (11/19, 58\%) were panel surveys where a cohort of participants, who often were provided a mobile phone upon a face-to-face enrollment, were surveyed multiple times.

Conclusions: Very few reports of population-level MPS were identified. Of the MPS that were identified, the majority of surveys were conducted using CATI. Due to the limited number of identified IVR and SMS surveys, the relative advantages and disadvantages among the three survey modalities cannot be adequately assessed. The majority of MPS were sent to mobile phone numbers that were collected from a previously administered household survey. There is limited evidence on whether a random digit dialing (RDD) approach or a simple random sample of mobile network provided list of numbers can produce a population representative survey.

(J Med Internet Res 2017;19(5):e139) doi: 10.2196/jmir.7428 


\section{KEYWORDS}

survey methodology; cellular phone; interactive voice response; short messages service; computer-assisted telephone interview; mobile phone surveys

\section{Introduction}

National and subnational surveys are important for monitoring disease burden, prioritizing resource allocation, and evaluating public health policies [1]. In low- and middle-income countries (LMICs), such surveys typically rely on face-to-face interviews conducted at the respondent's household. Household surveys are conducted infrequently, typically due to high costs in personnel and transportation associated with household survey implementation and the face-to-face nature of data collection [2-5]. In addition, household surveys require considerable amounts of time for data collection, data management, and data analysis which impedes the speed at which data become publically available. A more frequent surveillance of population health would allow for a more timely evaluation of implemented public health policies and response to public health emergencies.

To address the high costs and time requirements associated with household surveys, higher income countries have developed and employed telephone surveys to collect population-level estimates of health and demographics [6-8]. As mobile phone ownership and access become more common globally, with 94 subscriptions per 100 inhabitants in developing countries [9], opportunities exist to leverage mobile-health technologies and communication channels to revolutionize the current methods of data collection in LMIC. Rather than conducting household surveys, respondents can now be interviewed over their own personal mobile phone through the use of short message service (SMS), interactive voice response (IVR), and computer-assisted telephone interviews (CATI) survey modalities; collectively called mobile phone surveys (MPS).

SMS surveys utilize text messages to send survey questions to participants' mobile phones. Data are then collected from participants via SMS responses to these questions. Inherent in this survey modality is the requirement of a literate population, which may be challenging in some LMICs. IVR surveys counter the challenges in SMS surveys by using automated, prerecorded questions. With IVR surveys, respondents interact with a preprogrammed database which contains both questions and a series of preset answers which are linked to a specific numeric key, or numeric response on a touch-tone phone keypad (eg, "Press 1 for Yes"). CATI surveys most closely mimic a household survey by employing human interviewers or call centers. Interviewers follow a script provided by a software program to survey participants.

The purpose of this review was to document the current landscape of MPS being used for population-level data collection in LMICs, with a focus on IVR-, SMS-, and CATI-collected data and to identify key survey metrics, such as response and completion rates for each of the MPS modalities. Such a review is currently not available in the literature, and this comprises an important assessment of current knowledge for future research [10].

\section{Methods}

We conducted a systematic search of the literature according to the Preferred Reporting Items for Systematic Reviews and Meta-Analyses (PRISMA) [11] in March-April of 2015 to find articles that used MPS for population-level data collection in LMICs. There were no restrictions on year that records were published. Using a predefined search strategy that included a range of terms for mobile phone, interactive voice response, text message, survey, questionnaire, and data collection, we searched the primary and gray literature using PubMed, Embase, Scopus, Global Health, Web of Science, Cochrane Reviews, and Proquest Digital Dissertations databases for article titles, key words, and abstracts pertaining to MPS. Search terms were uniquely created for each database to capitalize on the database's classification of articles (see Multimedia Appendix 1).

Records that matched the search criteria or were preidentified as relevant articles before the literature review $(n=6)$ were imported into RefWorks. The 6 preidentified articles were obtained through our knowledge of the World Bank's initiative to promote MPS in LMICs. After applying an automatic filter for duplicates, the remaining abstracts and titles were manually filtered for additional study duplication and clearly irrelevant topics, such as nonhuman studies. Two research assistants conducted a primary screening of each record's titles and abstracts. Primary inclusion criteria included the following: (1) SMS used to collect data from a respondent, (2) IVR used to collect data from a respondent, (3) CATI or call centers used to collect data from a respondent, (4) a combination of the above, (5) surveys where a respondent provided answers using their mobile phone. Primary exclusion criteria included the following: (1) mobile phone used by a human enumerator to conduct an in-person survey, (2) use of mobile phone for other activities but not data collection, or (3) no indication that mobile phones were used for data collection. Records were included for secondary screening if there was any uncertainty as to whether the article included an MPS.

Articles that met primary screening criteria underwent a secondary full-text review and were screened for the following secondary inclusion and exclusion criteria. Secondary inclusion criteria included (1) SMS, IVR, or CATI was used for data collection and (2) MPS was intended to be population-representative. Secondary exclusion criteria included (1) study was not conducted in a LMIC as defined by the World Bank [12], (2) respondents were interviewed in-person by an enumerator using a mobile phone, and (3) surveys were sent to respondent's landline telephone number. Records were included independent of the survey's content (ie, health, agriculture, economics, and so on). Articles that were written in languages other than English were not reviewed.

Two research assistants extracted data from all included articles. Disagreements in data extraction were resolved by consensus between the two research assistants. Data were entered into an 
Excel (Microsoft) worksheet and grouped by survey modality to populate tables. For panel surveys where the same respondent answered a series of surveys over time, the response, completion, and refusal rates from the first round of surveys were abstracted and presented in the identified manuscripts.

\section{Results}

\section{Overview}

The literature search identified 11,568 records. After removing duplicates, 6625 records underwent a primary screening of titles and abstracts (Figure 1). Full-text articles $(n=656)$ were then screened using secondary inclusion and exclusion criteria. Overall, we identified 11 articles that employed 19 MPS (CATI, IVR, or SMS) surveys to collect population estimates across a range of topics. Nine articles presented results for 10 CATI surveys $(10 / 19,53 \%)$ [13-21]. Two articles discussed the findings of 6 IVR surveys $(6 / 19,32 \%)$ [13,22]. Three SMS surveys were identified from 2 articles $(3 / 19,16 \%)[13,23]$.

Figure 1. Flow diagram of the study. CATI: computer-assisted telephone interview; IVR: interactive voice response; SMS: short message service. One article included surveys for CATI $(n=2)$, IVR $(n=2)$, and SMS $(n=2)$.

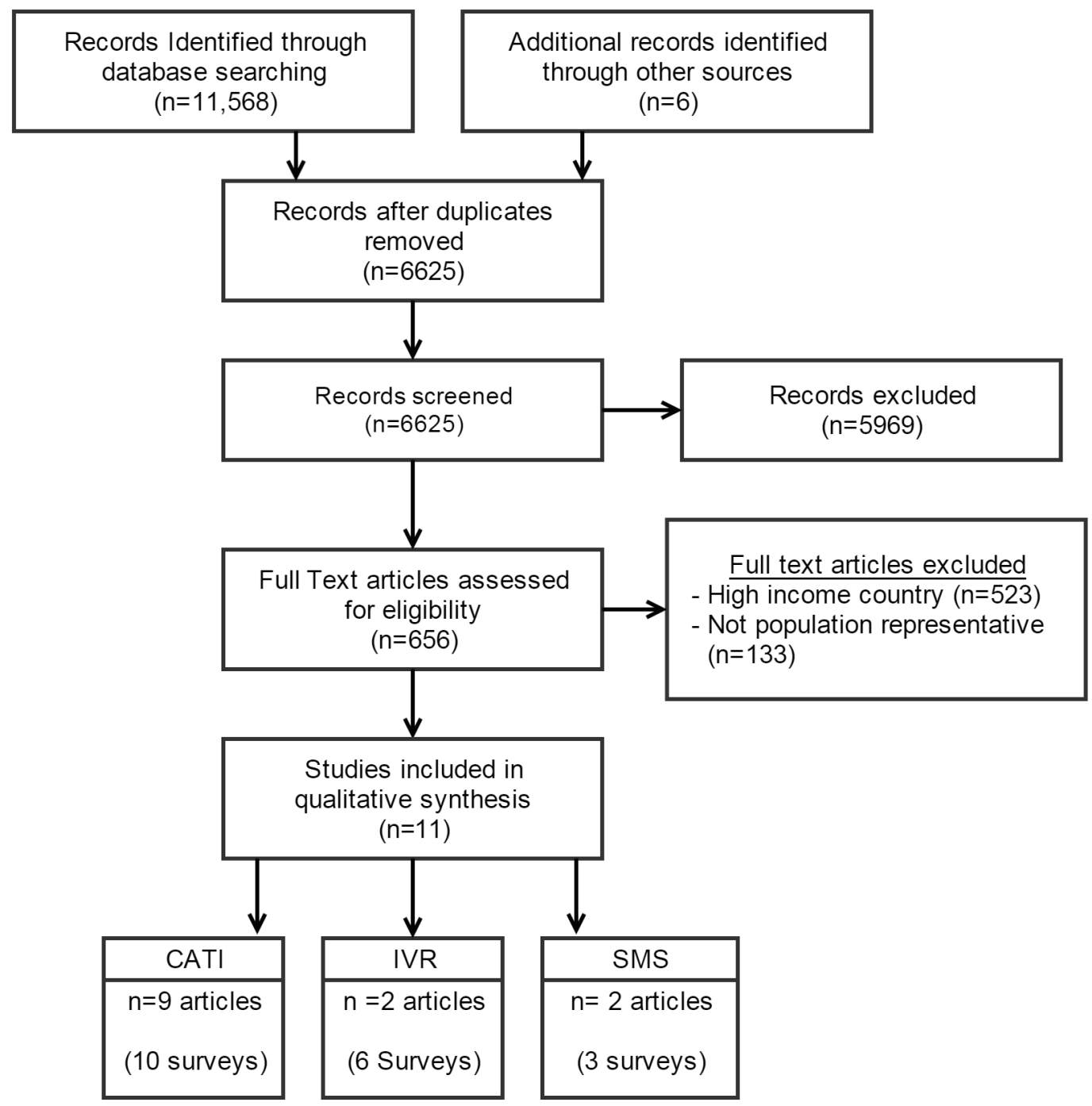

\section{CATI Surveys}

The majority of MPS implemented in LMICs were conducted by human interviewers, typically stationed at call centers equipped with CATI software (Table 1). The locations and questionnaire topics were diverse; CATI surveys were conducted in Bangladesh, Brazil, Honduras, Lebanon, Liberia, Mali, Peru, South Sudan, and Tanzania and covered topics on health and socioeconomics.
Of the 10 identified CATI surveys, 60\% (6/10) were implemented through the World Bank or as part of the Listening to Africa (L2A) and Listening to Latin America and the Caribbean (L2LAC) Initiatives [13,14,16-18]. In these initiatives, a population-representative sample of households was drawn and a baseline household visit was made; survey staff interviewed the selected household member in-person and provided training on how to answer future mobile phone panel surveys (Panel MPS). Panel MPS were typically sent monthly 
to collect information on general welfare questions, such as household assets, food security, and employment [24]. The literature review identified one Panel MPS in Tanzania that was not affiliated with the World Bank and L2A or L2LAC [15]. The number of survey rounds or waves ranged from 2 to 33 with a typical interval of 3-6 weeks between each wave. In $71 \%$ $(5 / 7)$ of the Panel MPS, mobile phones were provided to all participants [14-16] or only provided to those who did not already own one [13].

Three studies employed a cross-sectional CATI survey, rather than a panel MPS [19-21]. Mobile phones were not provided to any of these participants. The Lebanese survey sampled participants who had provided a phone number during the nationwide Nutrition and Noncommunicable Disease Risk Factor Survey [20]. The median time between the household and CATI survey was 1.8 months. In Bangladesh and Brazil, participants for noncommunicable diseases (NCD) risk factor surveys were sampled from a list of subscribers provided by a mobile network operator (MNO) [19] or through random digit dialing (RDD), respectively [21]. Since 2006, Brazil's Ministry of Health has conducted annual telephone surveys for risk and protective factors of NCD. Articles that presented VIGITEL surveys where the sampling frame contained only landline telephone numbers were excluded as the purpose of this review was to document MPS [25-29].

Overall, the response rates and completion rates for CATI surveys were highly variable, ranging from $30 \%$ to $98 \%$ and from $35 \%$ to $100 \%$, respectively, although completion rates were only presented in $30 \%$ (3/10) of surveys. It is likely that for studies that did not report, the completion rate may near
$100 \%$ as one study commented that it is the interviewer's job to make sure all questions are answered [13]. In the three studies that reported refusal rate, estimates ranged from $2 \%$ to $8 \%$ $[17,20,21]$. For Panel MPS, typically, panel attrition was highest at the first CATI following the household baseline survey, with attrition and nonresponse rates plateauing over the duration of the panel.

Varying airtime incentive amounts, tied to survey completion, were randomized in $40 \%$ (4/10) of CATI surveys [13,14,18], all of which were Panel MPS, to evaluate their effect on survey response and completion rates. In two surveys that did not contain a control arm (ie, no incentive), there was either no discernible effect between the low and high incentive amount on response rates [18], or the higher incentive arm had lower response rate as compared with the lower incentive arm [14]. In Peru and Honduras, panelists were randomized to one of the following three arms: (1) no incentive, (2) US \$1 airtime, and (3) US \$5 airtime [13]. In Honduras, both incentive arms significantly improved survey response throughout the panel, as compared with the control arm. In Peru, results were not disaggregated by survey modality (CATI, IVR, and SMS). The authors reported no appreciable difference in the first survey's response rate by the study arm; with similar gains in the two incentive arms at minimizing panel attrition over the duration of the study. Of note, the study's authors indicate that the incentive arm contained the majority of people who were provided a study-sponsored mobile phone. An additional three panel surveys provided a fixed US \$1-2 airtime incentive to all panelists [15-17]. Incentives were not used in the three cross-sectional surveys [19-21]. 
Table 1. Computer-assisted telephone interviews (CATI) or human operator-administered surveys ( $\mathrm{n}=10$ surveys, 9 articles).

\begin{tabular}{|c|c|c|c|c|c|c|}
\hline Author & $\begin{array}{l}\text { Country } \\
\text { (sample size) }\end{array}$ & Survey type & Sampling frame & Phone given & $\begin{array}{l}\text { Response } \%^{\mathrm{a}} \\
(\text { completion \%) }\end{array}$ & $\begin{array}{l}\text { Average time to com- } \\
\text { plete } \\
\text { (\# questions) }\end{array}$ \\
\hline \multirow[t]{2}{*}{ Ballivian et al [13] } & $\begin{array}{l}\text { Peru } \\
(n=384)\end{array}$ & $\begin{array}{l}\text { Panel } \\
\text { (n=6 waves) }\end{array}$ & Household collected & If not owned & $\begin{array}{l}51 \% \\
100 \%\end{array}$ & (10) \\
\hline & $\begin{array}{l}\text { Honduras } \\
(\mathrm{n}=600)\end{array}$ & $\begin{array}{l}\text { Panel } \\
\text { ( } \mathrm{n}=2 \text { waves) }\end{array}$ & Household collected & If not owned & $88 \%$ & (10) \\
\hline Demombynes et al [14] & $\begin{array}{l}\text { South Sudan } \\
(\mathrm{n}=1007)\end{array}$ & $\begin{array}{l}\text { Panel } \\
\text { (n=4 waves) }\end{array}$ & Household collected & Yes & $69 \%$ & $\begin{array}{l}15-20 \mathrm{~min} \\
(16-26)\end{array}$ \\
\hline Dillon [15] & $\begin{array}{l}\text { Tanzania } \\
(\mathrm{n}=195)\end{array}$ & $\begin{array}{l}\text { Panel } \\
\text { (n=14 waves) }\end{array}$ & Household collected & Yes & $98 \%$ overall & $\approx 27 \mathrm{~min}$ \\
\hline Etang-Ndip et al [16] & $\begin{array}{l}\text { Mali } \\
(\mathrm{n}=501)\end{array}$ & $\begin{array}{l}\text { Panel } \\
\text { ( } \mathrm{n}=6 \text { waves) }\end{array}$ & Household collected & Yes & $99 \%$ & $20-25 \min$ \\
\hline Himelein [17] & $\begin{array}{l}\text { Liberia } \\
(n=2137)\end{array}$ & $\begin{array}{l}\text { Panel } \\
\text { ( } \mathrm{n}=2 \text { waves) }\end{array}$ & Household collected & No & $30 \%$ & $\approx 15 \mathrm{~min}$ \\
\hline Hoogeven et al [18] & $\begin{array}{l}\text { Tanzania } \\
(\mathrm{n}=458)\end{array}$ & $\begin{array}{l}\text { Panel } \\
\text { (n=33 waves) }\end{array}$ & Household collected & No & $75 \%$ overall & $19 \mathrm{~min}$ \\
\hline Islam et al [19] & $\begin{array}{l}\text { Bangladesh } \\
(\mathrm{n}=3378)\end{array}$ & Cross-sectional & Mobile network operator & No & $61 \%$ & \\
\hline Mahfoud et al [20] & $\begin{array}{l}\text { Lebanon } \\
(\mathrm{n}=771)\end{array}$ & Cross-sectional & Household collected & No & $(82 \%)$ & $8 \mathrm{~min}$ \\
\hline Moura et al [21] & $\begin{array}{l}\text { Brazil } \\
(n=1207)\end{array}$ & Cross-sectional & Random digit dialing & No & $(\approx 35 \%)$ & $5 \mathrm{~min}$ \\
\hline
\end{tabular}

${ }^{\mathrm{a}}$ For panel surveys, the response, completion, and refusal rates listed are for the first round of MPS unless otherwise indicated.

Table 2. IVR-administered surveys ( $\mathrm{n}=6$ surveys, 2 articles).

\begin{tabular}{|c|c|c|c|c|c|c|}
\hline Author & $\begin{array}{l}\text { Country } \\
\text { (sample size) }\end{array}$ & Survey type & Sampling frame & Phone given & $\begin{array}{l}\text { Response } \%^{\mathrm{a}} \\
(\text { completion \%) }\end{array}$ & $\begin{array}{l}\text { Average time to com- } \\
\text { plete (\# (questions) }\end{array}$ \\
\hline \multirow[t]{3}{*}{ Ballivian et al [13] } & Peru & Panel & Household collected & If not owned & $20 \%$ & $(10 \mathrm{Q})$ \\
\hline & $(n=383)$ & ( $\mathrm{n}=6$ waves) & & & $75 \%$ & \\
\hline & $\begin{array}{l}\text { Honduras } \\
(\mathrm{n}=600)\end{array}$ & $\begin{array}{l}\text { Panel } \\
\text { ( } \mathrm{n}=2 \text { waves) }\end{array}$ & Household collected & If not owned & $40 \%$ & $(10 \mathrm{Q})$ \\
\hline \multirow[t]{8}{*}{ Leo et al [22] } & Afghanistan & Cross-sectional & Random digit dialing & No & $31 \%$ & 4-5 min \\
\hline & $(\mathrm{n}=2123)$ & & & & $(30 \%)$ & $(10 \mathrm{Q})$ \\
\hline & Ethiopia & Cross-sectional & Random digit dialing & No & $19 \%$ & $4-5 \mathrm{~min}$ \\
\hline & $(\mathrm{n}=2258)$ & & & & $(23 \%)$ & $(10 \mathrm{Q})$ \\
\hline & Mozambique & Cross-sectional & Random digit dialing & No & $9 \%$ & $4-5 \min$ \\
\hline & $(n=2229)$ & & & & $(38 \%)$ & $(10 \mathrm{Q})$ \\
\hline & Zimbabwe & Cross-sectional & Random digit dialing & No & $8 \%$ & $4-5 \min$ \\
\hline & $(\mathrm{n}=2192)$ & & & & $(51 \%)$ & $(10 \mathrm{Q})$ \\
\hline
\end{tabular}

${ }^{\mathrm{a}}$ For panel surveys, the response, completion, and refusal rates listed are for the first round of MPS unless otherwise indicated.

\section{IVR Surveys}

MPS that employed IVR were less frequently covered in existing literature (Table 2). Our literature review identified two articles that described the findings of 6 IVR surveys to collect population-level estimates [13,22]. One article employed a standardized methodology across 4 countries-Afghanistan, Ethiopia, Mozambique, and Zimbabwe - to collect demographic and standard of living information [22]. Participants were selected through RDD with a demographic quota system and were not provided a mobile phone. The remaining 2 IVR surveys were conducted in Honduras and Peru as part of the L2LAC 
initiative, where participants had previously completed a baseline household survey and were provided a mobile phone as needed [13]. All 6 surveys utilized a 10-question survey; 4 surveys reported that respondents, on average, interacted with the survey for 2-3 min and for those who completed the 10-question survey, it took between 4 and 5 min [22]. Response rates were typically higher for IVR surveys that were sent to mobile phone numbers collected from a previous household survey (20\% and 40\%) than from those using an RDD approach $(8 \%, 9 \%, 19 \%$, and $31 \%)$.A wide range $(23-75 \%)$ of survey completion rates was observed.

The effect of airtime incentives to improve survey response and completion rates [22] and panel attrition rates [13] was evaluated across the 6 surveys and produced mixed results. One article randomized RDD participants to a control arm, 4-min airtime incentive transfer, and a raffle for a 2-h airtime incentive; where participants in the two airtime arms were eligible for the incentive if the survey was completed [22]. In Zimbabwe, the transfer and raffle incentives significantly improved the proportion of participants who completed the survey; while in Mozambique, only the raffle incentive was found to be significant. A similar evaluation was conducted in Afghanistan and Ethiopia, but the authors commented that there were problems with the randomization and allocation of study arm. In Honduras, those who were randomized to either US \$1 or US $\$ 5$ of airtime incentive showed higher response rates than those who did not receive an incentive [13]. As described previously, response rates were not disaggregated by survey modality in Peru.

\section{SMS Surveys}

Although data collection via SMS surveys is relatively common in LMICs, very few studies aimed to collect data on a representative sample of a population (Table 3 ). One study sampled 982,708 phone numbers from a network of 18 million prepaid mobile phone subscribers in Mexico to participate in a surveillance program regarding influenza-like illness [23]. Mobile phone subscribers were sent a text message from the Ministry of Health, inviting them to participate in a 6-question survey. The surveillance program resulted in a $5.8 \%$ response rate. The mean age of respondents was 25 years and nearly $90 \%$ of surveys were completed within $24 \mathrm{~h}$ of the initial contact. No incentives were provided.

As part of the previously described L2LAC, SMS surveys were also deployed in Peru and Honduras to collect population representative estimates [13]. The response rates for the first round of SMS surveys were $30 \%$ and $45 \%$ in Peru and
Honduras, respectively. Approximately $80 \%$ of participants completed the ten question survey in Peru. In Honduras, providing either US $\$ 1$ or US $\$ 5$ of airtime significantly improved response rate, as compared with those who did not receive any airtime incentive.

\section{Comparison of Survey Metrics Across Different MPS Modalities}

Only two surveys compared key survey metrics such as response and completion rates across MPS. The response rate for the first round of Panel MPS was highest for CATI (Honduras, 88\%; Peru, $51 \%)$, followed by SMS $(45 \% ; 30 \%)$ and IVR $(40 \% ; 20 \%)$ [13]. In Peru, CATI showed a $100 \%$ completion rate; with completion rates of $80 \%$ and $75 \%$ in SMS and IVR surveys, respectively. In the same set of surveys, the reliability of the respondent's answer was assessed through a test-retest procedure. Cronbach alpha coefficient for CATI, IVR, and SMS were $.69, .86$, and .74 , respectively, indicating that IVR resulted in the most reliable measurements. Of note, such survey metrics have not been compared across survey modalities using sampling frames other than household collected phone numbers (eg, RDD or MNO provided).

\section{Excluded Studies}

Several large SMS surveys were identified but were excluded because they did not seek to attain representativeness. Two SMS surveys recruited participants through social media platforms. $[30,31]$ Demographic information regarding the users of these platforms was not included thus making it difficult to assess the representativeness of respondents. Two studies attempted to achieve a subnational sample through opt-in recruitment, potentially introducing selection bias $[32,33]$. Numerous studies used SMS and IVR surveys as a data collection tool within a research study [34-54] or as a surveillance instrument for health care workers [55-59] and were excluded from the review.

\section{Discussion}

\section{Principal Findings}

Our literature review identified very few reports of MPS being used to collect population-level estimates. CATI surveys $(n=10)$, most frequently relying on a household baseline survey to collect mobile phone numbers and implemented by the World Bank, were the most common type of MPS reported. When there was a household collection of mobile phone numbers, frequently, the implementing team conducted panel surveys (repeated MPS to the same respondent over time). 
Table 3. SMS-administered surveys ( $\mathrm{n}=3$ surveys, 2 articles).

\begin{tabular}{|c|c|c|c|c|c|c|}
\hline Author & $\begin{array}{l}\text { Country } \\
\text { (sample size) }\end{array}$ & Survey type & Sampling frame & Phone provided & $\begin{array}{l}\text { Response } \%^{\mathrm{a}} \\
(\text { completion } \% \text { ) }\end{array}$ & $\begin{array}{l}\text { Average time to com- } \\
\text { plete (\# questions) }\end{array}$ \\
\hline \multirow[t]{3}{*}{ Ballivian et al [13] } & Peru & Panel & Household collected & If not owned & $30 \%$ & $(10 Q)$ \\
\hline & $(\mathrm{n}=677)$ & ( $\mathrm{n}=6$ waves) & & & $80 \%$ & \\
\hline & $\begin{array}{l}\text { Honduras } \\
(\mathrm{n}=600)\end{array}$ & $\begin{array}{l}\text { Panel } \\
\text { (n=7 waves) }\end{array}$ & Household collected & If not owned & $45 \%$ & $(10 \mathrm{Q})$ \\
\hline Lajous et al [23] & $\begin{array}{l}\text { Mexico } \\
(\mathrm{n}=982,708)\end{array}$ & Cross-sectional & Mobile network operator & No & $6 \%$ & $(6 \mathrm{Q})$ \\
\hline
\end{tabular}

${ }^{\mathrm{a}}$ For panel surveys, the response, completion, and refusal rates listed are for the first round of MPS unless otherwise indicated.

The selection of the MPS modality has important downstream impacts on costs, survey metrics, and data quality, with each modality having its strengths and weaknesses [13,14] (Table 4). Evidence from one study that compared costs across the three modalities found that SMS and IVR surveys are less expensive than CATI surveys [13]. The primary cost of IVR and SMS surveys are airtime needed to deliver the survey, with additional costs for initial programming and monitoring survey delivery. CATI surveys, in addition to the cost of airtime and programming, also require personnel-human interviewers and supervisors - to conduct the survey, making their delivery more costly than IVR or SMS surveys [13]. The higher costs of CATI surveys are partially offset by the advantage of having a human to conduct the survey. This offers an opportunity for personalized responses to clarify any confusion a respondent may have, potentially resulting in higher quality data and lower levels of survey attrition. This benefit is supported from surveys in Peru and Honduras where response and completion rates were highest for CATI, as compared with IVR and SMS surveys. Additional studies that use a standardized approach to examine the effect of survey modality on survey response, completion, and refusal rates are needed.

Table 4. Strengths and weaknesses of mobile phone surveys (MPS) by modality (adapted from Demombynes (2013) and Ballivian (2013)).

\begin{tabular}{ll}
\hline Strengths & Weaknesses \\
\hline
\end{tabular}

\section{Computer-assisted telephone interview (CATI)}

Respondent's familiarity with a phone call interaction

Operators can clarify questions

Ability to build rapport with respondents

Does not require respondents to be literate

\section{Interactive voice Response (IVR)}

Mimics a phone call

Does not require respondents to be literate

Automated surveys allows for quick data collection

Minimizes interviewer bias

Less expensive than CATI due to its automation

\section{Short Message Service (SMS)}

Respondents answer at their convenience

Automated surveys allows for quick data collection

Minimizes interviewer bias

Less expensive than CATI due to its automation

The majority of identified studies relied on household-collected mobile phone numbers as the sampling frame [13-18,20]. Like the MPS modality, the choice of sampling frame has implications on cost, key survey metrics, and potential representatives of a MPS. In an RDD approach there will be a significant proportion of randomly generated telephone numbers that do not exist or are not registered [60]; this represents an
Resource intensive (operators, supervisors, training)

Inter-rater reliability concerns

Potential for interviewer bias

Respondents may be less truthful for sensitive questions

Requires sustained network signal

Requires sustained network signal

Respondents may not be familiar with "robot" calls

Potential for respondent to be distracted while answering the survey

Poor audio quality of some phones

May not reach illiterate respondents

Requires network signal, possibility of lost messages

Question length limited by character count

Inbox can become full

added cost, particularly for CATI surveys and their reliance on human operators, as more telephone calls need to be made in order to achieve the survey's sample size. Similarly, and dependent on the equation used for calculation [61], the response and completion rates may appear to be artificially lower in an RDD sample as compared with sampling frames, such as 
household collected or MNO-provided ones, which ensure that the mobile phone numbers collected are active.

The use of incentives to improve response and completion (ie, cooperation) rates in telephone and postal surveys in high-income countries is well-documented [62]. Similarly, incentivizing participants through the provision of free airtime has the potential to increase the response and completion rates and the demographic representativeness of MPS, yet the findings from the few randomized trials provides inconclusive evidence on whether these interventions are effective [13,14,18,22]. Additional research studies on the use of airtime incentives and other mechanisms to improve survey performance and outcomes are needed.

Access to a mobile phone and mobile network coverage are implicit factors in a MPS's ability to generate population-representative estimates. Moreover, the "digital divide" phenomenon, where mobile phone ownership is associated with socioeconomic status, may also pose challenges with obtaining representative estimates-although evidence suggests this divide is shrinking [63]. To increase the likelihood of a survey's representativeness, household sampling methodologies can be applied to obtain a sample of household-collected mobile phone numbers. However, this requires an initial investment of human and financial resources to collect the phone numbers and is more appropriate for cohort studies or panel surveys where the initial investment will be recouped with each subsequent survey. An RDD sampling frame is more suitable for cross-sectional surveys and is the standard sampling approach for telephone surveys [60]. Our review identified very few MPS that employed RDD, but the evidence suggests that it is feasible to obtain a representative sample and that it is dependent on the saturation levels of mobile phone ownership and, to a lesser extent, linguistic fractionalization
[22]. Still, options exist for obtaining population-representative results using RDD [64].

\section{Limitations}

The literature review and its inclusion and exclusion criteria identified very few articles that employed SMS ( $n=2$ articles) or IVR surveys $(n=2)$ to collect population representative estimates. There are three potential reasons for the infrequent use of IVR and SMS surveys. First, the search terms used in our literature review did not identify all relevant articles. Second, the pilot testing results from the L2A and L2LAC initiatives may have artificially driven the overrepresentativeness of CATI surveys identified in our literature review. Before the implementation of the initiatives, a series of pilot tests identified that CATI surveys yielded higher completion rates than IVR and SMS surveys; leading the World Bank to adopt the CATI modality as its preferred survey. Thirdly, the MPS field is in its infancy phase and there may truly be very few reports of attempts at population-representative surveys using IVR and SMS. An additional limitation is the presentation of the response and completion rates. The majority of the manuscripts did not present the equations used to calculate these rates, as recommended by the American Association for Public Opinion Research [61].

\section{Conclusions}

In conclusion, the state of MPS to collect population level estimates of health and other indicators remains nascent. Additional research that directly compares the costs, key survey metrics such as contact, response, completion, and refusal rates, and demographic representativeness across the different survey modalities is needed [10]. Still, if MPS are found to produce valid and reliable data, their use has the potential to compliment traditional household surveys and benefit existing surveillance efforts by leveraging their lower costs to allow for a more frequent monitoring of the population's health.

\section{Acknowledgments}

The studies described as part of the research agenda are funded by the Bloomberg Philanthropies. This funding agency had no role in the preparation of this manuscript.

\section{Conflicts of Interest}

None declared.

\section{Multimedia Appendix 1}

Examples of search terms used.

[PDF File (Adobe PDF File), 10KB-Multimedia Appendix 1]

\section{References}

1. Thacker S, Berkelman R. Public health surveillance in the United States. Epidemiol Rev 1988;10:164-190. [Medline: 3066626]

2. Lukwago L, Nanyunja M, Ndayimirije N, Wamala J, Malimbo M, Mbabazi W, et al. The implementation of Integrated Disease Surveillance and Response in Uganda: a review of progress and challenges between 2001 and 2007. Health Policy Plan 2013 Jan;28(1):30-40 [FREE Full text] [doi: 10.1093/heapol/czs022] [Medline: 22669899]

3. Somda ZC, Perry HN, Messonnier NR, Djingarey MH, Ki SO, Meltzer MI. Modeling the cost-effectiveness of the integrated disease surveillance and response (IDSR) system: meningitis in Burkina Faso. PLoS One 2010 Sep 28;5(9):e13044 [FREE Full text] [doi: 10.1371/journal.pone.0013044] [Medline: 20927386] 
4. Somda ZC, Meltzer MI, Perry HN, Messonnier NE, Abdulmumini U, Mebrahtu G, et al. Cost analysis of an integrated disease surveillance and response system: case of Burkina Faso, Eritrea, and Mali. Cost Eff Resour Alloc 2009 Jan 08;7:1 [FREE Full text] [doi: 10.1186/1478-7547-7-1] [Medline: 19133149$]$

5. Toscano CM, Vijayaraghavan M, Salazar-Bolaños HM, Bolaños-Acuña HM, Ruiz-González AI, Barrantes-Solis T, iVPD Working Team. Cost analysis of an integrated vaccine-preventable disease surveillance system in Costa Rica. Vaccine 2013;31(Suppl 3):C88-C93 [FREE Full text] [doi: 10.1016/j.vaccine.2013.05.036] [Medline: 23777698]

6. Liu B, Brotherton JM, Shellard D, Donovan B, Saville M, Kaldor JM. Mobile phones are a viable option for surveying young Australian women: a comparison of two telephone survey methods. BMC Med Res Methodol 2011;11:159 [FREE Full text] [doi: 10.1186/1471-2288-11-159] [Medline: 22114932]

7. Iachan R, Pierannunzi C, Healey K, Greenlund KJ, Town M. National weighting of data from the Behavioral Risk Factor Surveillance System (BRFSS). BMC Med Res Methodol 2016;16(1):155 [FREE Full text] [doi: 10.1186/s12874-016-0255-7] [Medline: 27842500]

8. Brick JM, Edwards WS, Lee S. Sampling telehone numbers and adults, interview length, and weighting in the California Health Interview Survey cell phone pilot study. Public Opin Q 2007;71(5):793-813. [doi: 10.1093/poq/nfm052]

9. International Telecommunication Union. The World in 2016: ICT Facts and Figures URL: http://www.itu.int/en/ITU-D/ Statistics/Pages/stat/default.aspx [accessed 2016-12-12] [WebCite Cache ID 6mgkxF0WI]

10. Hyder A, Wosu A, Gibson D, Labrique A, Ali J, Pariyo G. Noncommunicable disease risk factors and mobile phones: a proposed research agenda. J Med Internet Res 2017;19(5):e133 [FREE Full text] [doi: 10.2196/jmir.7246]

11. Moher D, Liberati A, Tetzlaff J, Altman D. Preferred reporting items for systematic reviews and meta-analyses: the PRISMA statement. Ann Intern Med 2009;151(4):264-9, W64. [Medline: 19622511]

12. The World Bank. datahelpdesk.worldbank. World Bank Country and Lending Groups URL: https://datahelpdesk. worldbank.org/knowledgebase/articles/906519-world-bank-country-and-lending-groups [accessed 2017-04-08] [WebCite Cache ID 6pZjlupkO]

13. Ballivian A, Azevedo J, Durbin W, Rios J, Godoy J, Borisova C, et al. catalog.ihsn. Washington DC: The World Bank; 2013. Listening to LAC: Using Mobile Phones for High Frequency Data Collection: Final Report URL: http://catalog. ihsn.org/index.php/catalog/4775/related materials [accessed 2017-04-08] [WebCite Cache ID 6pZkHmMxa]

14. Demombynes G, Gubbins P, Romeo A. openknowledge.worldbank. Washington, DC: World Bank; 2013. Challenges and Opportunities of Mobile Phone-Based Data Collection Evidence from South Sudan URL: https://openknowledge. worldbank.org/handle/10986/12169 [accessed 2017-04-08] [WebCite Cache ID 6pZkZbibF]

15. Dillon B. Using mobile phones to collect panel data in developing countries. J Int Dev 2011;24(4):518-527. [doi: 10.1002/jid.1771]

16. Etang-Ndip A, Hoogeveen JG, Lendorfer J. openknowledge.worldbank. Washington, DC: World Bank; 2015. Socioeconomic impact of the crisis in North Mali on displaced people URL: https://openknowledge.worldbank.org/handle/10986/21868 [accessed 2017-04-08] [WebCite Cache ID 6pZkoxY0V]

17. Himelein K. openknowledge.worldbank. Washington, DC: World Bank; 2015. The socio-economic impacts of Ebola in Liberia: results from a high frequency cell phone survey URL: https://openknowledge.worldbank.org/handle/10986/21624 [accessed 2017-04-08] [WebCite Cache ID 6pZl3bmci]

18. Hoogeveen J, Croke K, Dabalen A, Demombynes G, Giugale M. Collecting high frequency panel data in Africa using mobile phone interviews. Can J Dev Stud 2014;35(1):186-207. [doi: 10.1080/02255189.2014.876390]

19. Islam K, Rahman M, Sharif A, Al KA, Alam Z, Rahman M. Introducing mobile phone for interview in surveillance system in Bangladesh: validation of the method. ASTMH 2013;89(5 Suppl 1):78-152. [doi: 10.4269/ajtmh.2013.89.78]

20. Mahfoud Z, Ghandour L, Ghandour B, Mokdad AH, Sibai AM. Cell phone and face-to-face interview responses in population-based surveys: how do they compare? Field methods 2014;27(1):39-54. [doi: 10.1177/1525822X14540084]

21. Moura EC, Claro RM, Bernal R, Ribeiro J, Malta DC, Morais Neto O. A feasibility study of cell phone and landline phone interviews for monitoring of risk and protection factors for chronic diseases in Brazil. Cad Saude Publica 2011;27(2):277-286 [FREE Full text] [Medline: 21359464]

22. Leo B, Morello R, Mellon J, Peixoto T, Davenport S. cgdev. 2015. Do Mobile Surveys Work in Poor Countries URL: https://www.cgdev.org/publication/do-mobile-phone-surveys-work-poor-countries-working-paper-398 [accessed 2017-04-08] [WebCite Cache ID 6pZmoclrN]

23. Lajous M, Danon L, López-Ridaura R, Astley CM, Miller JC, Dowell SF, et al. Mobile messaging as surveillance tool during pandemic (H1N1) 2009, Mexico. Emerg Infect Dis 2010;16(9):1488-1489 [FREE Full text] [doi: 10.3201/eid1609.100671] [Medline: 20735942]

24. The World Bank. Worldbank. Listening to Africa 2016 URL: http://www.worldbank.org/en/programs/listening-to-africa [accessed 2017-04-08] [WebCite Cache ID 6pZn8yVpL]

25. Andrade SS, Malta DC, Iser BM, Sampaio PC, Moura LD. Prevalence of self-reported arterial hypertension in Brazilian capitals in 2011 and analysis of its trends in the period between 2006 and 2011. Rev Bras Epidemiol 2014;17(Suppl 1):215-226. [doi: 10.1590/1809-4503201400050017] [Medline: 25054265] 
26. Ferreira AD, César CC, Malta DC, Andrade AC, Ramos CG, Proietti FA, et al. Validity of data collected by telephone survey: a comparison of VIGITEL 2008 and 'Saúde em Beagá' survey. Rev Bras Epidemiol 2011;14(Suppl 1):16-30 [FREE Full text] [Medline: 22002139]

27. Francisco PM, Barros MB, Segri NJ, Alves MC, Cesar CL, Malta DC. Comparison of estimates for the self-reported chronic conditions among household survey and telephone survey--Campinas (SP), Brazil. Rev Bras Epidemiol 2011;14(Suppl 1):5-15 [FREE Full text] [Medline: 22002138]

28. Iser BP, Malta DC, Duncan BB, de Moura L, Vigo A, Schmidt MI. Prevalence, correlates, and description of self-reported diabetes in brazilian capitals - results from a telephone survey. PLoS One 2014;9(9):e108044 [FREE Full text] [doi: 10.1371/journal.pone.0108044] [Medline: 25255096]

29. Malta DC, Andrade SC, Claro RM, Bernal RT, Monteiro CA. Trends in prevalence of overweight and obesity in adults in 26 Brazilian state capitals and the Federal District from 2006 to 2012. Rev Bras Epidemiol 2014;17(Suppl 1):267-276 [FREE Full text] [Medline: 25054269]

30. Murgor M. A mobile phone-based survey on knowledge of cervical cancer HPV vaccination in Kenya. Asia Pac J Clin Oncol 2014;10(S9):19-20. [doi: 10.1111/ajco.12332]

31. Weimann E, Stuttaford M. Consumers' perspectives on national health insurance in South Africa: using a mobile health approach. JMIR Mhealth Uhealth 2014 Oct 28;2(4):e49 [FREE Full text] [doi: 10.2196/mhealth.3533] [Medline: 25351980]

32. de Lepper AM, Eijkemans MJ, van Beijma H, Loggers J, Tuijn C, Oskam L. Response patterns to interactive SMS health education quizzes at two sites in Uganda: a cohort study. Trop Med Int Health 2013;18(4):516-521 [FREE Full text] [doi: 10.1111/tmi.12059] [Medline: 23297650]

33. Vahdat HL, L'Engle KL, Plourde KF, Magaria L, Olawo A. There are some questions you may not ask in a clinic: providing contraception information to young people in Kenya using SMS. Int J Gynaecol Obstet 2013;123(Suppl 1):e2-e6 [FREE Full text] [doi: 10.1016/j.ijgo.2013.07.009] [Medline: 24012514]

34. Andreatta P, Debpuur D, Danquah A, Perosky J. Using cell phones to collect postpartum hemorrhage outcome data in rural Ghana. Int J Gynaecol Obstet 2011;113(2):148-151. [doi: 10.1016/j.ijgo.2010.11.020] [Medline: 21420086]

35. Curran K, Mugo NR, Kurth A, Ngure K, Heffron R, Donnell D, et al. Daily short message service surveys to measure sexual behavior and pre-exposure prophylaxis use among Kenyan men and women. AIDS Behav 2013;17(9):2977-2985 [FREE Full text] [doi: 10.1007/s10461-013-0510-4] [Medline: 23695519]

36. de Tolly KM, Constant D. Integrating mobile phones into medical abortion provision: intervention development, use, and lessons learned from a randomized controlled trial. JMIR Mhealth Uhealth 2014;2(1):e5 [FREE Full text] [doi: 10.2196/mhealth.3165] [Medline: 25098569]

37. Du X, Wang W, Helena van Velthoven M, Chen L, Scherpbier RW, Zhang Y, et al. mHealth Series: text messaging data collection of infant and young child feeding practice in rural China - a feasibility study. J Glob Health 2013;3(2):020403 [FREE Full text] [doi: 10.7189/jogh.03.020403] [Medline: 24363921]

38. Haberer J, Kiwanuka J, Nansera D, Wilson IB, Bangsberg DR. Challenges in using mobile phones for collection of antiretroviral therapy adherence data in a resource-limited setting. AIDS Behav 2010;14(6):1294-1301 [FREE Full text] [doi: 10.1007/s10461-010-9720-1] [Medline: 20532605]

39. Haberer J. Real-time HIV antiretroviral therapy adherence monitoring in a resource-limited setting. Ann Behav Med 2011;41(1 Supplement):S143.

40. Irani M, Abdoli S, Bijan I, Parvizy S, Fatemi N, Amini M. Strategies to overcome type 1 diabetes-related social stigma in the Iranian society. Iran J Nurs Midwifery Res 2014;19(5):456-463 [FREE Full text] [Medline: 25400672]

41. Kew S. Text messaging: an innovative method of data collection in medical research. BMC Res Notes 2010;3:342 [FREE Full text] [doi: 10.1186/1756-0500-3-342] [Medline: 21172018]

42. Kwon HS, Cho JH, Kim HS, Lee JH, Song BR, Oh JA, et al. Development of web-based diabetic patient management system using short message service (SMS). Diabetes Res Clin Pract 2004;66(Suppl 1):S133-S137. [doi: 10.1016/j.diabres.2003.10.028] [Medline: 15563964]

43. Li Y, Wang W, van Velthoven MH, Chen L, Car J, Rudan I, et al. Text messaging data collection for monitoring an infant feeding intervention program in rural China: feasibility study. J Med Internet Res 2013 Dec 04;15(12):e269 [FREE Full text] [doi: 10.2196/jmir.2906] [Medline: 24305514]

44. Li Y, Wang W, Wu Q, van Velthoven MH, Chen L, Du X, et al. Increasing the response rate of text messaging data collection: a delayed randomized controlled trial. J Am Med Inform Assoc 2015;22(1):51-64 [FREE Full text] [doi: 10.1136/amiajnl-2014-002845] [Medline: 25332355]

45. Mukadi P, Gillet P, Lukuka A, Mbatshi J, Otshudiema J, Muyembe J, et al. External quality assessment of reading and interpretation of malaria rapid diagnostic tests among 1849 end-users in the Democratic Republic of the Congo through Short Message Service (SMS). PLoS One 2013;8(8):e71442 [FREE Full text] [doi: 10.1371/journal.pone.0071442] [Medline: 23967211]

46. Munro ML, Lori JR, Boyd CJ, Andreatta P. Knowledge and skill retention of a mobile phone data collection protocol in rural Liberia. J Midwifery Womens Health 2014;59(2):176-183 [FREE Full text] [doi: 10.1111/jmwh.12155] [Medline: 24655593] 
47. Nejmeh B, Dean T. The charms application suite: A community-based mobile data collection and alerting environment for HIV/AIDS orphan and vulnerable children in Zambia. In: Service-Learning in the Computer and Information Sciences: Practical Applications in Engineering Education. Hoboken, NJ: John Wiley \& Sons; 2012.

48. Rotheram-Borus M, Richter L, Van Rooyen H, van Heerden A, Tomlinson M, Stein A, et al. Project Masihambisane: a cluster randomised controlled trial with peer mentors to improve outcomes for pregnant mothers living with HIV. Trials 2011;12:2 [FREE Full text] [doi: 10.1186/1745-6215-12-2] [Medline: 21205302]

49. Scott W, Weina PJ. Texting away malaria: a new alternative to directly observed therapy. Mil Med 2013;178(2):e255-e259. [doi: 10.7205/MILMED-D-12-00257] [Medline: 23764334]

50. Sidney K, Antony J, Rodrigues R, Arumugam K, Krishnamurthy S, D'souza G, et al. Supporting patient adherence to antiretrovirals using mobile phone reminders: patient responses from South India. AIDS Care 2012;24(5):612-617. [doi: 10.1080/09540121.2011.630357] [Medline: 22150088]

51. van Heerden AC, Norris S, Tollman S, Stein A, Richter L. Field lessons from the delivery of questionnaires to young adults using mobile phones. Soc Sci Comput Rev 2013;32(1):105-112. [doi: 10.1177/0894439313504537]

52. Yoonessi A, Ekhtiari H. Text messages as a tool for assessing public concern about drug problems. Int J Drug Policy 2013;24(6):624-627. [doi: 10.1016/j.drugpo.2013.06.002] [Medline: 23849717]

53. Zirong H, Junqing W, Coffey P, Kilbourne-Brook M, Yufeng Z, Wang C, et al. Performance of the woman's condom among couples in Shanghai, China. Eur J Contracept Reprod Health Care 2012;17(3):212-218. [doi: 10.3109/13625187.2012.663016] [Medline: 22497293]

54. Zolfaghari M, Mousavifar SA, Pedram S, Haghani H. The impact of nurse short message services and telephone follow-ups on diabetic adherence: which one is more effective? J Clin Nurs 2012;21(13-14):1922-1931. [doi: 10.1111/j.1365-2702.2011.03951.x] [Medline: 22239205]

55. Armstrong K, Liu F, Seymour A, Mazhani L, Littman-Quinn R, Fontelo P, et al. Evaluation of txt2MEDLINE and development of short messaging service-optimized, clinical practice guidelines in Botswana. Telemed J E Health 2012;18(1):14-17. [doi: 10.1089/tmj.2011.0014] [Medline: 22150636]

56. Githinji S, Kigen S, Memusi D, Nyandigisi A, Wamari A, Muturi A, et al. Using mobile phone text messaging for malaria surveillance in rural Kenya. Malar J 2014;13:107 [FREE Full text] [doi: 10.1186/1475-2875-13-107] [Medline: 24642130]

57. Rajatonirina S, Heraud J, Randrianasolo L, Orelle A, Razanajatovo N, Raoelina Y, et al. Short message service sentinel surveillance of influenza-like illness in Madagascar, 2008-2012. Bull World Health Organ 2012;90(5):385-389 [FREE Full text] [doi: 10.2471/BLT.11.097816] [Medline: 22589573]

58. Randrianasolo L, Raoelina Y, Ratsitorahina M, Ravolomanana L, Andriamandimby S, Heraud J, et al. Sentinel surveillance system for early outbreak detection in Madagascar. BMC Public Health 2010;10:31 [FREE Full text] [doi: 10.1186/1471-2458-10-31] [Medline: 20092624]

59. Schuttner L, Sindano N, Theis M, Zue C, Joseph J, Chilengi R, et al. A mobile phone-based, community health worker program for referral, follow-up, and service outreach in rural Zambia: outcomes and overview. Telemed J E Health 2014;20(8):721-728 [ [FREE Full text] [doi: 10.1089/tmj.2013.0240] [Medline: 24926815]

60. Potthoff R. Telephone sampling in epidemiologic research: to reap the benefits, avoid the pitfalls. Am J Epidemiol 1994;139(10):967-978. [Medline: $\underline{8178785]}$

61. The American Asssociation for Public Opinion Research. Standard definitions: Final dispositions of case codes and outcome rates for surveys. 9th edition. Oakbrook Terrace, IL: AAPOR; 2016.

62. Singer E, Ye C. The use and effects of incentives in surveys. Ann Am Acad Pol Soc Sci 2012;645(1):112-141. [doi: $10.1177 / 0002716212458082]$

63. Tran MC, Labrique AB, Mehra S, Ali H, Shaikh S, Mitra M, et al. Analyzing the mobile "digital divide": changing determinants of household phone ownership over time in rural bangladesh. JMIR Mhealth Uhealth 2015;3(1):e24 [FREE Full text] [doi: 10.2196/mhealth.3663] [Medline: 25720457]

64. Labrique AB, Blynn E, Ahmed S, Gibson DG, Pariyo GW, Hyder AA. Health surveys using mobile phones in developing countries: automated active strata monitoring and other statistical considerations for improving precision and reducing biases. J Med Internet Res 2017;19(5):e121 [FREE Full text] [doi: 10.2196/jmir.7329]

\section{Abbreviations}

CATI: computer-assisted telephone interviews

IVR: interactive voice response

L2A: Listening to Africa

L2LAC: Listening to Latin America and the Caribbean

LMIC: low- and middle-income countries

MNO: mobile network operator

MPS: mobile phone surveys

NCD: noncommunicable diseases

PRISMA: Preferred Reporting Items for Systematic Reviews and Meta-Analyses 
RDD: random digit dialing

SMS: short message service

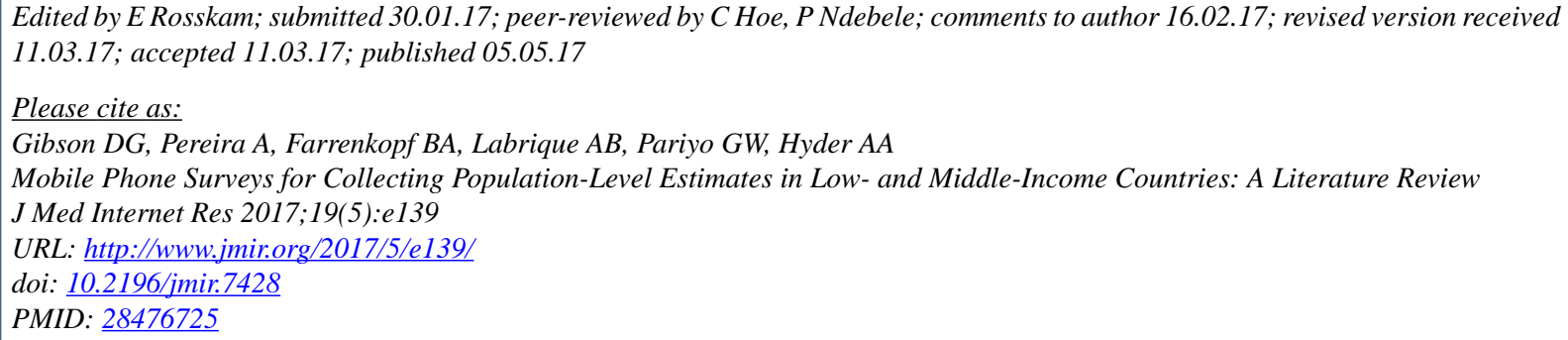

CDustin G Gibson, Amanda Pereira, Brooke A Farrenkopf, Alain B Labrique, George W Pariyo, Adnan A Hyder. Originally published in the Journal of Medical Internet Research (http://www.jmir.org), 05.05.2017. This is an open-access article distributed under the terms of the Creative Commons Attribution License (http://creativecommons.org/licenses/by/2.0/), which permits unrestricted use, distribution, and reproduction in any medium, provided the original work, first published in the Journal of Medical Internet Research, is properly cited. The complete bibliographic information, a link to the original publication on http://www.jmir.org/, as well as this copyright and license information must be included. 